\title{
Body weight, egg production, and egg quality traits of gray, brown, and white varieties of Japanese quail (Coturnix coturnix japonica) in coastal climatic condition of Odisha
}

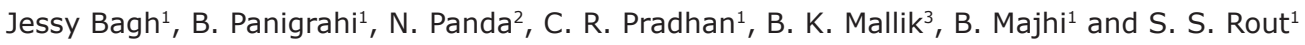

1. Department of Livestock Production and Management, College of Veterinary Science and Animal Husbandry, Orissa University of Agriculture and Technology, Bhubaneswar, Odisha, India; 2. Department of Animal Nutrition, College of Veterinary Science and Animal Husbandry, Orissa University of Agriculture and Technology, Bhubaneswar, Odisha, India; 3. Central Poultry Development Organization, Eastern Region, Bhubaneswar, Odisha, India. Corresponding author: Jessy Bagh, e-mail: jessybagh123@gmail.com,

BP: bpanigrahi65@yahoo.com, NP: npandaouat@gmail.com, CRP: pradhancr@gmail.com, BKM: bandim64@gmail.com, BM: brunda2013ouat@gmail.com, SSR: drsubhransu0412@yahoo.com

Received: 11-04-2016, Accepted: 02-07-2016, Published online: 10-08-2016

doi: 10.14202/vetworld.2016.832-836 How to cite this article: Bagh J, Panigrahi B, Panda N, Pradhan CR, Mallik BK, Majhi B, Rout SS (2016) Body weight, egg production, and egg quality traits of gray, brown, and white varieties of Japanese quail (Coturnix coturnix japonica) in coastal climatic condition of Odisha, Veterinary World, 9(8): 832-836.

\begin{abstract}
Aim: The present study was conducted to evaluate the performance of gray, brown, and white varieties of Japanese quail (Coturnix coturnix japonica) with respect to body weight, egg production, and egg quality traits in the coastal climatic condition of Odisha.

Materials and Methods: A total of 500-day-old straight run Japanese quail chicks of three varieties, viz., gray, brown, and white were randomly selected and reared in deep litter system at Central Poultry Development Organization, Eastern Region, Bhubaneswar. The weekly body weight of the birds was recorded till their egg production stage (up to 6 weeks of age). The average egg production was recorded every biweekly from $6^{\text {th }}$ to $20^{\text {th }}$ week. Exterior and interior quality of eggs from each variety was determined at 6 weeks of age.

Results: The initial average weekly body weight of three varieties did not differ $(p>0.05)$ among the varieties. However, from $1^{\text {st }}$ to $6^{\text {th }}$ week significantly higher body weight was observed in gray than white and brown. Brown varieties had reached 50\% egg production 1 week earlier than gray and white. Brown had higher peak hen day (HD) production or henhoused egg production followed by white and gray. External quality such as: Egg weight, egg length, egg width, volume, shape index, shell weight, shell thickness depicted no significant difference among the varieties except circumference length and circumference width, which were significantly higher $(\mathrm{p} \leq 0.05)$ in gray varieties than brown varieties. Internal egg characteristics such as: Albumen length, albumen width, albumen height, albumen index, yolk length, yolk width, yolk height, yolk index, albumen weight, yolk weight, Haugh unit revealed no significance difference among the varieties.

Conclusion: It may be summarized from the findings that gray excelled in body weight followed by white and brown. Egg production potential in terms of hen house egg production or HD egg production was higher for brown followed by white and gray in the coastal climatic condition of Odisha.
\end{abstract}

Keywords: body weight, egg production potential, egg quality traits, quail.

\section{Introduction}

The Japanese quail (Coturnix coturnix japonica) is emerging as a promising poultry to the resource-poor rural farmers of India for minimal capital and managemental requirements in rearing. It is the smallest farmed avian species [1] and becoming popular in commercial poultry sector for meat and egg production. Raising quail provides a resource for poor families with meat and eggs [2]. The females are very prolific because they begin laying eggs on average at 6 weeks and can lay between 250 and 300 eggs a year [3]. Furthermore, the quail is an efficient converter of feed with each egg

Copyright: Bagh, et al. Open Access. This article is distributed under the terms of the Creative Commons Attribution 4.0 International License (http://creativecommons.org/licenses/by/4.0/), which permits unrestricted use, distribution, and reproduction in any medium, provided you give appropriate credit to the original author(s) and the source, provide a link to the Creative Commons license, and indicate if changes were made. The Creative Commons Public Domain Dedication waiver (http://creativecommons.org/ publicdomain/zero/1.0/) applies to the data made available in this article, unless otherwise stated. a female deposits an edible package of $8 \%$ of her own body weight as compared to $3 \%$ in case of chicken [4].

Egg quality is the more important price contributing factor in table and hatching eggs [5]. Therefore, the economic success of a laying flock solely depends on the total number of quality eggs produced [6]. Besides the performance of three varieties, the present study would be helpful to express a preference for the appropriate one in this situation.

Although a lot of works have been carried out on the performance of egg production potential and egg quality traits of quail, it is desirable to know the performance of the above-mentioned varieties under hot and humid conditions of Odisha, the information on which is limited.

\section{Materials and Methods}

\section{Ethical approval}

Experiments were carried out following the guidelines of the Institutional Animal Ethics Committee. 


\section{Location and period of experiment}

The experiment was carried out at the Central Poultry Development Organization (CPDO), Government of India, Eastern Region, Bhubaneswar. The experiment was conducted during the period starting from January to May 2014.

\section{Experimental programme}

A total of 500-day-old straight run thrifty and healthy Japanese quail chicks of three varieties, viz., gray, brown, and white were randomly selected and reared in deep litter system at CPDO, Eastern Region, Bhubaneswar. The experimental birds were placed in the naturally ventilated house and were raised in the deep litter system. The feed and water were given ad libitum and fed with conventional starter, grower and layer rations, respectively. Natural daylight was provided at the beginning of the experiment and then light hour was increased by $1 / 2 \mathrm{~h} /$ day. Vaccination and preventive medication were followed as per standard procedure during the experimental period. There was provision of one nest box with three compartments for every 20 laying quails in the layer house for ensuring clean egg production from the farm was determined according to the method of Debata et al. [7]. Average age at sexual maturity of the three varieties was taken by recording the age at first egg production of all the birds. The average egg production mainly from $6^{\text {th }}$ to $20^{\text {th }}$ week, i.e., 15 weeks interval was recorded every biweekly. Then, cumulative egg production up to 20 weeks was also calculated. External and internal egg quality of 10 freshly laid eggs from each of the three varieties of quail was taken for the study at 6 weeks of age.

\section{Measurement of external egg quality}

Egg weight was individually recorded on a digital balance to the nearest of $0.01 \mathrm{~g}$ accuracy. Egg length (along the longitudinal axis) and egg width (along the equatorial axis) were measured with the help of digital calipers to the nearest to $0.01 \mathrm{~mm}$. Shape index of the individual egg was calculated as the ratio of maximum egg width to length (\%) as per Schuttz [8]. Volume of the egg was measured by liquid displacement technique using the $1 \mathrm{~L}$ graduated cylinder setup. Circumference length and circumference width were measured by measuring tape. After the eggs were broken, egg shells were washed under slightly flowing water to remove remaining albumen and were left to dry at room temperature for $24 \mathrm{~h}$; then, they were weighed in the digital balance. Shell thickness along with membrane was measured at the broad end, narrow end, and equatorial parts of each egg to the nearest of $0.01 \mathrm{~mm}$ with the help of screw gauze and shell thickness was obtained from the average value.

\section{Measurement of internal egg quality}

With the help of a Vernier caliper, the length and width of the thick albumen and yolk were measured in millimeter. The height of the thick albumen and yolk was measured at maximum height with the help of spherometer to $0.01 \mathrm{~mm}$ accuracy on a leveled glass table. The albumen index and the yolk index were worked out according to the formula of Heiman and Carver [9] and Sharp and Powell [10], respectively. Haugh unit was calculated according to the formula of Haugh [11]. The yolk separated from the albumen was weighed together with the membrane to get the yolk weight [12]. Albumen weight was calculated by subtracting the yolk and shell weight from egg weight.

\section{Statistical analysis}

The data obtained from the study were statistically analyzed according to Snedecor and Cochran [13]. The data were analyzed for analysis of variance to test the difference between means wherever necessary.

\section{Results}

\section{Body weight}

The average weekly body weight of the three varieties from day old to 6 weeks is presented in the Table-1. The initial body weight of three varieties ranged from 7.13 to $7.50 \mathrm{~g}$, which did not differ significantly $(\mathrm{p}>0.05)$ among the varieties. In the $6^{\text {th }}$ week, the body weight of gray, brown, and white was 173.79, 168.23, and $172.62 \mathrm{~g}$, respectively. Higher body weight was observed in gray than the white and brown in a $6^{\text {th }}$ week. It was also seen that brown varieties have less body weight than white. As the quails under the study attain sexual maturity around 5-6 weeks, so the body weights were recorded up to $6^{\text {th }}$ week.

\section{Egg production}

The hen-housed $(\mathrm{HH})$ egg production and hen day (HD) egg production of three varieties from 6 to 20 weeks are presented in Table-2. Brown varieties had reached $50 \%$ egg production 1 week earlier

Table-1: Weekly body weight $(\mathrm{g})$ of three varieties of Japanese quail.

\begin{tabular}{lcccc}
\hline Age (weeks) & Gray & Brown & White & SEM \\
\hline 0 & $7.50 \pm 0.15$ & $7.38 \pm 0.12$ & $7.13 \pm 0.13$ & $N S$ \\
1 & $18.37^{\mathrm{c}} \pm 0.16$ & $20.26^{\mathrm{b}} \pm 0.18$ & $21.63^{\mathrm{a}} \pm 0.19$ & 0.02 \\
2 & $48.86^{\mathrm{a}} \pm 0.38$ & $43.97^{\mathrm{c}} \pm 0.38$ & $47.95^{\mathrm{b}} \pm 0.37$ & 0.04 \\
3 & $92.26^{\mathrm{a}} \pm 0.67$ & $84.37^{\mathrm{c}} \pm 0.73$ & $91.34^{\mathrm{b}} \pm 0.80$ & 0.08 \\
4 & $120.43^{\mathrm{b}} \pm 0.78$ & $112.98^{\mathrm{c}} \pm 0.92$ & $134.46^{\mathrm{a}} \pm 0.50$ & 0.07 \\
5 & $152.80^{\mathrm{a}} \pm 0.90$ & $146.16^{\mathrm{c}} \pm 0.97$ & $149.05^{\mathrm{b}} \pm 0.87$ & 0.20 \\
6 & $173.79^{\mathrm{a}} \pm 1.01$ & $168.23^{\mathrm{c}} \pm 0.95$ & $172.62^{\mathrm{b}} \pm 1.25$ & 0.30 \\
\hline
\end{tabular}

Means showing different superscripts in a row differ significantly $(p<0.05)$. SEM: Standard error of mean, NS: Not significant 
than gray and white. Brown had higher (99.7\%) peak HD production followed by white $(89.2 \%)$ and gray $(87.3 \%)$. The hen-housed egg production (\%) over time followed the same pattern as observed for hen day egg production (\%).

\section{External egg characteristics}

As far as the external egg qualities of the egg are concerned, the circumference length and circumference width were significantly higher $(p \leq 0.05)$ in gray varieties than brown varieties, and no difference was seen between gray and white varieties (Table-3).

Table-2: $\mathrm{HH}$ and HD egg production (\%).

\begin{tabular}{|c|c|c|c|c|c|c|}
\hline \multirow[t]{2}{*}{$\begin{array}{l}\text { Age in } \\
\text { weeks }\end{array}$} & \multicolumn{3}{|c|}{$\begin{array}{l}\text { HH egg production } \\
(\%)\end{array}$} & \multicolumn{3}{|c|}{$\begin{array}{c}\text { HD egg production } \\
(\%)\end{array}$} \\
\hline & Gray & Brown & White & Gray & Brown & White \\
\hline 6 & & & & 0 & & \\
\hline & & & & & & \\
\hline & & & & & & \\
\hline 9 & & & & & & \\
\hline & & & & & & \\
\hline 11 & 86 & & & & & \\
\hline 12 & 86.3 & & & & & \\
\hline 13 & 81.0 & & & 1 & & 86.8 \\
\hline 14 & 82.7 & 95.24 & 80.22 & 3.74 & 98.72 & 82.0 \\
\hline 15 & 82.8 & 88.72 & 83.96 & 85.05 & 94.03 & 86.3 \\
\hline 16 & 64.6 & 81.95 & 72. & 66.3 & 87. & 75.0 \\
\hline 17 & 63.5 & 77.6 & 72. & 65.6 & 83. & 75.2 \\
\hline 18 & 67.7 & 84.7 & 77. & 69.99 & 91.23 & 80.1 \\
\hline 19 & 71.2 & & & 73. & & 79.6 \\
\hline 20 & 65.00 & 80.45 & 73.41 & 67.16 & 86.65 & 76.0 \\
\hline
\end{tabular}

$\mathrm{HH}$ : Hen house, HD: Hen day
The egg length, egg width, volume, and shape index of these varieties depicted no significant difference among themselves.

\section{Internal egg characteristics}

Albumen length, albumen width, albumen height, albumen index, yolk length, yolk width, yolk height, yolk index, albumen weight, Haugh unit, and yolk weight are presented in Table- 4 . The values were not significantly different $(\mathrm{p} \geq 0.05)$ between gray, brown, and white varieties.

\section{Discussion}

Body weight

In the present study, the white had higher body weight in $1^{\text {st }}$ week than brown and gray, but from $2^{\text {nd }}$ to $6^{\text {th }}$ week, gray had higher body weight which could be attributable to the genotype for higher rate of gain of the variety. These findings are in line with those of Vali et al. [14], who reported significant body weight variation in two quail strains at 35,42 , and 49 days of age. Strain effect on body weight at different ages is reported by different authors Aljumaily [15] and Jatoi et al. [16]. Aljumaily [15] reported that brown had higher body weight than white strain at 2, 3, 4, and 5 weeks of age $(p<0.05)$, which is not in agreement of present study finding.

\section{Egg production}

In present study, brown birds had more HH egg production than gray and white, where brown birds are lighter than gray and white. Similarly, Jatoi et al. [16]

Table-3: External egg quality traits of three varieties of Japanese quail.

\begin{tabular}{lcccc}
\hline Parameters & Gray & Brown & White & SEM \\
\hline Egg weight $(\mathrm{g})$ & $11.6 \pm 0.03$ & $10.58 \pm 0.30$ & $10.58 \pm 0.26$ & $\mathrm{NS}$ \\
Egg length $(\mathrm{mm})$ & $32.51 \pm 0.33$ & $31.43 \pm 0.23$ & $31.43 \pm 0.40$ & $\mathrm{NS}$ \\
Egg width $(\mathrm{mm})$ & $25.83 \pm 0.88$ & $24.74 \pm 0.24$ & $24.33 \pm 0.27$ & $\mathrm{NS}$ \\
Circumference length $(\mathrm{mm})$ & $9.53^{\mathrm{b}} \pm 0.40$ & $8.79^{\mathrm{c}} \pm 0.11$ & $9.69^{\mathrm{a}} \pm 0.06$ & 0.04 \\
Circumference width $(\mathrm{mm})$ & $8.37^{\mathrm{a}} \pm 0.08$ & $7.76^{\mathrm{b}} \pm 0.14$ & $8.42^{\mathrm{a}} \pm 0.2$ & 0.05 \\
Volume $(\mathrm{ml})$ & $10.40 \pm 0.37$ & $9.70 \pm 0.26$ & $10.10 \pm 0.31$ & $\mathrm{NS}$ \\
Shape index $(\%)$ & $72.88 \pm 3.14$ & $72.13 \pm 0.88$ & $69.93 \pm 1.51$ & $\mathrm{NS}$ \\
Shell weight $(\mathrm{g})$ & $1.56 \pm 0.01$ & $1.42 \pm 0.02$ & $1.5 \pm 0.06$ & $\mathrm{NS}$ \\
Shell thickness $(\mathrm{mm})$ & $0.26 \pm 1.61$ & $0.27 \pm 2.76$ & $0.25 \pm 0.01$ & $\mathrm{NS}$ \\
\hline
\end{tabular}

Values bearing different superscripts in a row differ significantly $(p<0.05)$. SEM: Standard error of mean, NS: Not significant

Table-4: Internal egg quality traits of three varieties of Japanese quail.

\begin{tabular}{lcccc}
\hline Parameters & Gray & Brown & White & SEM \\
\hline Albumen width $(\mathrm{mm})$ & $32.73 \pm 0.65$ & $35.32 \pm 1.25$ & $33.49 \pm 0.76$ & $\mathrm{NS}$ \\
Albumen length $(\mathrm{mm})$ & $43.34 \pm 1.46$ & $44.80 \pm 1.51$ & $45.92 \pm 1.77$ & $\mathrm{NS}$ \\
Albumen height $(\mathrm{mm})$ & $4.76 \pm 0.01$ & $4.73 \pm 0.01$ & $4.66 \pm 0.23$ & $\mathrm{NS}$ \\
Albumen weight $(\mathrm{g})$ & $5.20 \pm 0.17$ & $4.78 \pm 0.19$ & $5.40 \pm 0.12$ & $\mathrm{NS}$ \\
Albumen index & $14.10 \pm 0.16$ & $13.20 \pm 0.52$ & $13.15 \pm 0.01$ & $\mathrm{NS}$ \\
Haugh unit & $91.01 \pm 1.57$ & $91.28 \pm 1.71$ & $90.90 \pm 1.20$ & $\mathrm{NS}$ \\
Yolk length $(\mathrm{mm})$ & $24.57 \pm 0.32$ & $24.81 \pm 0.51$ & $25.23 \pm 0.64$ & $\mathrm{NS}$ \\
Yolk width $(\mathrm{mm})$ & $23.11 \pm 0.25$ & $23.76 \pm 0.32$ & $23.90 \pm 0.86$ & $\mathrm{NS}$ \\
Yolk height $(\mathrm{mm})$ & $11.15 \pm 0.01$ & $10.86 \pm 0.01$ & $10.66 \pm 0.31$ & $\mathrm{NS}$ \\
Yolk weight $(\mathrm{g})$ & $3.80 \pm 0.06$ & $3.42 \pm 0.08$ & $3.50 \pm 0.13$ & $\mathrm{NS}$ \\
Yolk index & $48.05 \pm 0.22$ & $45.25 \pm 0.31$ & $45.36 \pm 0.03$ & $\mathrm{NS}$ \\
\hline
\end{tabular}

SEM: Standard error of mean, NS: Not significant 
in another study with 4 different close-bred (three local and one imported) Japanese quails reported that the maximum egg production was recorded in the small weight category and minimum in the heavy size birds. Similar findings have also been observed by North and Bell [17] and Ipek et al. [18] in poultry birds. Findings are in quite agreement with those of Nestor and Bacon [19] indicating that egg production decreased in heavy size and increased in low body weight strains of Japanese quail. High egg production in small quails in comparison to heavy quails could be due to more number of mature ovarian follicles in small quails. Jatoi et al. [16] also reported the similar findings.

\section{External egg characteristics}

Significantly higher $(p \leq 0.05) \quad$ circumference length and circumference width of gray and white varieties than brown varieties might be ascribed to the higher body weight of gray and white birds and lower egg production efficiency. This is in agreement with the findings of Hrncar et al. [20] that eggs of egg type Japanese quail weighed $11.48 \mathrm{~g}$, whereas the eggs of meat type Japanese quail weighed $13.06 \mathrm{~g}$ and also found that egg width $(\mathrm{mm})$ were 25.71 and 21.94, egg length $(\mathrm{mm})$ were 33.52 and 34.46 , egg shape index $(\%)$ were 76.70 and 78.18 , shell weight $(\mathrm{g})$ were 1.02 and 1.16 , and shell thickness $(\mathrm{mm})$ were 0.25 and 0.23 , for egg type and meat type quails, respectively. Zita et al. [21] calculated the egg weight and egg shape index in Pharaoh strain meat type quails as $12.52 \mathrm{~g}$ and $77.85 \%$, respectively similar to results obtained in the present experiment.

\section{Internal egg characteristics}

An experiment conducted by Hrncar et al. [20] found that albumen weight was $6.75 \mathrm{~g}$ and $7.52 \mathrm{~g}$, albumen length was 50.14 and 49.82, and albumen width was 38.27 and 38.27. Haugh unit was 87.28 and 87.56 in egg type and meat type quails, respectively. Due to the small size of eggs in the present experiment, the corresponding values obtained for albumen weight, albumen length, albumen width, and albumen height were less compared with the Hrncar et al. [20]. The Haugh unit values in this study $(90.90,91.01$, and 91.28 ) were in agreement with the data reported in literature for Haugh unit, such as 85.53-95.21 in quail by Altan et al. [22]. As for the yolk quality traits, the present study has shown a non-significant difference among the varieties. The values for yolk quality traits in this study were in agreement with the findings of Zita et al. [21]. The higher the Haugh unit and yolk index, the more desirable is the interior quality of the egg [23].

\section{Conclusion}

From this, it may be concluded that gray excelled in body weight followed by white and brown. Egg production potential, in terms of $\mathrm{HH}$ egg production or HD egg production, was higher for brown followed by white and gray.

\section{Authors' Contributions}

This present study is the major component of the work toward the M.V.Sc. thesis of the first author JB. JB carried out the work under the guidance of BP, NP, BKM, and CRP. BM and SSR: Helped during the study. NP guided in the statistical analysis of data. BP and CRP participated in draft and revision of the manuscript prepared by JB. All authors read and approved the final manuscript.

\section{Acknowledgments}

The authors are thankful to Dean, College of Veterinary Science and Animal Husbandry and Director, Central Poultry Development Organization, Eastern Region, for providing necessary facilities to conduct the research work. Funds to carry out this research work were provided by the Department of Livestock Production and Management, College of Veterinary Science and Animal Husbandry, Orissa University of Agriculture and Technology.

\section{Competing Interests}

The authors declare that they have no competing interests.

\section{References}

1. Panda, B. and Singh, R.P. (1990) Development in processing quail. Worlds Poult. Sci. J., 46: 219-234.

2. Dahouda, M., Adjolohoun, S., Montchowui, E.H., Senou, M., Hounsou, N.M.D., Amoussa, S., Vidjannagni, D.S., Abou, M. and Toleba, S.S. (2013) Growth performance of quails (Coturnix coturnix) fed on diets containing either animal or vegetable protein sources. Int. J. Poult. Sci., 12(7): 396-400.

3. Lucotte, G. (1974) La Production De La Caille. Edition: Vigot Frères, Paris. p77.

4. Martin, A.G., Franklin, W.M. and Maffiol, A. (1998) Quail: An Egg and Meat Production System. ECHO, USA.

5. Kocevski, D., Nikolova, N. and Kuzelov, A. (2011) The influence of strain and age on some egg quality parameters of commercial laying hens. Biotechnol. Anim. Husb., 27(4): 1649-1658

6. Monira, K.N., Salahuddin, M. and Miah, G. (2003) Effect of breed and holding period on egg quality characteristics of chicken. Int. J. Poult. Sci., 2(4): 261-263.

7. Debata, D., Panigrahi, B., Panda, N., Pradhan, C.R., Kanungo, S. and Panda, P.K. (2014) Egg production potential and egg quality traits of black rock, red Cornish and Vanaraja Chicken reared in coastal climatic condition of Odisha, India. Indian J. Anim. Res., 48(1): 91-93.

8. Schuttz, F.T. (1953) Analysis of egg shape in chickens. Biometrics, 9: 336.

9. Heiman, V. and Carver, J.S. (1936) The albumen index as a physical parameter of observed egg quality. Poult. Sci., 15: 141-144.

10. Sharp, P.F. and Powell, C.K. (1930) Decreased in internal quality of hens egg during storage as indicated by the yolk. Ind. Eng. Chem., 22: 909-910.

11. Haugh, R.R. (1937) The haugh unit for measuring egg quality. U.S. Egg Poult. Mag., 43: 552-555, 572-573.

12. Kul, S. and Seker, I. (2004) Phenotypic correlations between some external and internal egg quality traits in the Japanese quail (Coturnix coturnix japonica). Int. J. Poult. Sci., 3(6): 400-405.

13. Snedecor, G.W. and Cochran, W.G. (1980) Statistical Method. $7^{\text {th }}$ ed. The Iowa State University Press, Ames, Iowa, USA. 
14. Vali, N., Edriss, M.A. and Rahmani, H.R. (2005) Genetic parameters of body and some carcass traits in two quail strains. Int. J. Poult. Sci., 4(5): 296-300.

15. Aljumaily, T.K.H. (2011) The effect of Iraqians high environmental temperature on growth performance in two lines of Japanese quail. Int. J. Poult. Sci., 10(8): 634-636.

16. Jatoi, A.S., Sahota, A.W., Akram, M., Javed, K., Jaspal, M.H., Hussain, J., Mirani, A.H. and Mehmood, S. (2013) Effect of different body weight categories on the productive performance of four close-bred flocks of Japanese quail (Coturnix coturnix japonica). J. Anim. Plant Sci., 23(1): 7-13.

17. North, M.O. and Bell, D.D. (1990) Breeder management. In: Commercial Chicken Production Manual. $4^{\text {th }}$ ed. Van Nostrand Reinhold, New York, USA.

18. Ipek, A., Sahan, U. and Yilmaz, B. (2004) The effect of live weight, male to female ratio and breeder age on reproduction performance in Japanese quails (Coturnix coturnix japonica). S. Afr. J. Anim. Sci., 34(2): 130-134.
19. Nestor, K.E. and Bacon, W.L. (1982) Divergent sélection for body weight and yolk precursor in Coturnix coturnix japonica. 3. Correlated responses in mortality, reproduction traits and adult body weight. Poult. Sci., 61: 2137-2142.

20. Hrncar, C., Hanusova, E., Hanus, A. and Bujko, J. (2014) Effect of genotype on egg quality characteristics of Japanese quail (Coturnix japonica). Slovak J. Anim. Sci., 47(1): 6-11.

21. Zita, L., Ledvinka, Z. and Klesalova, L. (2013) The effect of the age of Japanese quails on certain egg quality traits and their relationships. Vet. Arch., 83(2): 223-232.

22. Altan, O., Oguz, I. and Akbas, Y. (1998) Effects of selection for high body weight and age of hen on egg characteristics in Japanese quail (Coturnix coturnix japonica). Turk. J. Vet. Anim. Sci., 25: 467-473.

23. Adeogun, I.O. and Amole, F.O. (2004) Some quality parameters of exotic chicken eggs under different storage conditions. Bull. Anim. Health Prod. Afr., 52: 43-47.

$* * * * * * * *$ 